\title{
Partisipasi Masyarakat Dalam Pengelolaan Hutan Mangrove Sebagai Kawasan Ekowisata (Studi Kasus Dusun Magelo’o Desa Reroroja Kecamatan Magepanda Kabupaten Sikka)
}

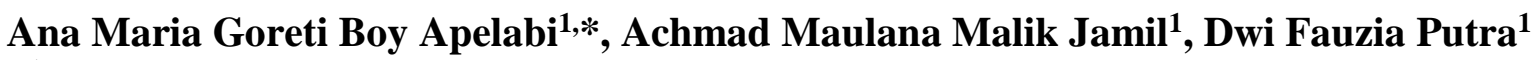 \\ ${ }^{1}$ Program Studi Pendidikan Geografi, Universitas Kanjuruhan Malang, Malang 65148, Indonesia \\ Email :*anaapelabi@gmail.com, maulana3188@unikama.com,dwifauziaputra@unikama.ac.id
}

Dikirim : 10 Juli 2019

Diterima: 1 September 2019

\begin{abstract}
Abstrak: Hutan mangrove di Dusun Magelo'o sudah mulai dimanfaatkan masyarakat dan pemerintah untuk dijadikan kawasan ekowisata. Tetapi, hutan mangrove di Dusun Magelo'o selama ini pengelolaannya belum maksimal dilihat dari masih kurang adanya penyediaan fasilitas penunjang kawasan wisata. Untuk itu partisipasi masyarakat sangat diperlukan dalam pengelolaan kawasan hutan mangrove menjadi kawasan ekowisata. Penelitian ini bertujuan untuk 1) mengetahui bentuk pengelolaan hutan mangrove, 2) mengetahui partisipasi masyarakat dalam pengelolaan hutan mangrove sebagai kawasan ekowisata dan 3) mengetahui faktor pendukung dan penghambat partisipasi masyarakat dalam pengelolaan hutan mangrove sebagai kawasan ekowisata. Penelitian ini menggunakan metode kualitatif dengan jenis penelitian studi kasus. Pengumpulan data dilakukan melalui observasi, wawancara dan dokumentasi. Analisis data dilakukan melalui pengumpulan data, reduksi data, penyajian data dan verification. Hasil penelitian ini diketahui bahwa bentuk pengelolaan kawasan hutan mangrove di Dusun Magelo'o adalah sebagai kawasan konservasi yang juga dimanfaatkan sebagai kawasan ekowisata dan pendidikan. Partisipasi yang diberikan masyarakat berupa pikiran dan tenaga. Tahapan partisipasi terdiri dari perencanaan, pengorganisasian, pelaksanaan, dan monitoring dan evaluasi. Faktor pendukung partisipasi masyarakat di Dusun Magelo'o berupa kesadaran dan kemauan. Sedangkan faktor penghambat pastisipasi masyarakat di Dusun Magelo'o adalah waktu bekerja dan ketergantungan kepada pihak-pihak tertentu. Saran agar penelitian ini dapat dijadikan acuan bagi peneliti lain untuk mengambil judul tentang partisipasi masyarakat dalam pengelolaan hutan mangrove sebagai kawasan ekowisata.
\end{abstract}

Kata kunci: partisipasi masyarakat, pengelolan hutan mangrove, ekowisata

\begin{abstract}
Mangrove forest in the Magelo'o hamlet has been utilized community and government used as ecotourism areas. But, the management of mangrove forests in the Hamlet of Magelo'o lack of provision of facilities tourism area supporting infrastructure. However, community participation is needed in the management of mangrove forest areas into areas ecotourism. This study aims to 1) know the forms of forest management mangrove, 2) knowing community participation in forest management mangrove as an ecotourism area and 3) know the supporting factors and inhibiting community participation in the management of mangrove forests as ecotourism area. This study uses qualitative methods with study case. Data collection done through observation, interviews and documentation. Data analysis carried out through data collection, data reduction, data presentation and verification. Results of this study note that the form of management is in mangrove forest area in Magelo'o Hamlet is a conservation area used as an ecotourism area. Community participation in the management of mangrove forests by give their idea and power. Stages participation which consists of planning, organizing, implementing, and monitoring and evaluation. Supporting factors community participation in the Hamlet Magelo'o in the form of awareness and willingness. While the inhibiting factor community participation in Magelo'o Hamlet is work time and dependence on certain parties. Suggestions for this research are expected to be used as a reference for other researchers to take the title of community participation in the management of mangrove forests as an ecotourism area.
\end{abstract}

Keywords: community participation, mangrove forest management, ecotourism 


\section{Pendahuluan}

Hutan mangrove sebagai suatu ekosistem mempunyai potensi keindahan alam dan lingkungan berupa komponen penyusun ekosistem yang terdiri vegetasi, biota atau organisme asosiasi, satwa liar dan lingkungan sekitarnya. Fungsi lingkungan yang diperoleh dari hutan mangrove antara lain sebagai habitat, daerah pemijahan, penyedia unsur hara, dan lain sebagainya. Hutan mangrove juga merupakan areal tempat penelitian, pendidikan dan ekowisata (Massaut dan FAO dalam Pratama, 2017).

Saat ini pemerintah Kabupaten Sikka mulai mencanangkan untuk menjadikan Kabupaten Sikka sebagai salah satu destinasi wisata di pulau Flores. Dilihat dari banyaknya potensi wisata yang ada di Kabupaten Sikka seperti wisata religi, wisata budaya, dan wisata alam berupa pantai. Wisata alam yang berpotensi untuk dikembangkan adalah wisata hutan mangrove yang banyak terdapat disepanjang pantai utara Kabupaten Sikka. Namun kawasan hutan mangrove ini belum dapat dimanfaatkan secara optimal oleh masyarakat dan pemerintah. Kawasan hutan mangrove yang mulai dikembangkan untuk dijadikan wisata terletak di Dusun Magelo'o.

Dusun Magelo'o merupakan salah satu Dusun yang mengalami dampak yang parah akibat bencana tsunami. Akibat dari bencana tsunami yang terjadi membuat salah seorang penduduk asal Atambua keturunan Cina bernama Viktor Emanuel Rayon atau yang lebih dikenal dengan nama Babah Akong berinsiatif untuk menanam mangrove. Penanaman mangrove merupakan salah satu alasan yang tepat bagi Babah Akong karena di lihat dari fungsi dan manfaatnya kawasan hutan mangrove sangat penting bagi lingkungan terutama di daerah pesisir, karena hutan mangrove mempunyai fungsi sebagai pelindung pesisir dari gelombang air laut yang menyebabkan abrasi pantai dan dari terpaan angin kencang yang dapat merusak bangunan yang berada di pesisir. Hutan mangrove juga berperan sebagai tempat berkembangbiaknya hewan-hewan dalam ekosistem mangrove seperti: burung, kepiting, kerang dan lainnya. Selain itu, hutan mangrove juga dapat dimanfaatkan sebagai kawasan edukasi atau tempat belajar alam bagi siswa-siswi maupun mahasiswa untuk mempelajari dan mengetahui lebih banyak mengenai hutan mangrove.

Ekowisata merupakan suatu kegiatan pariwisata yang berbeda dengan kegiatan pariwisata lainnya karena ekowisata memiliki karakter tersendiri yang khusus dengan adanya kepedulian pada pelestarian lingkungan dan dapat memberikan manfaat bagi masyarakat lokal. Ekowisata merupakan wisata yang berorientasi pada lingkungan dengan mengutamakan kepentingan terhadap perlindungan sumber daya alam dan industri kepariwisataan (META dalam Rangkuti, 2017). Jadi, makna ekowisata yaitu kegiatan wisata yang berbasis lingkungan yang mengutamakan kondisi lingkungannya agar tetap terjaga keasliannya.

Hutan mangrove di Dusun Magelo'o ini sudah mulai dimanfaatkan oleh masyarakat dan pemerintah untuk dijadikan kawasan ekowisata. Hal ini dilihat dari beberapa fasilitas yang sudah disediakan oleh masyarakat berupa jembatan dari bambu untuk menyusuri hutan mangrove. Selain jembatan, adapula fasilitas berupa menara bambu yang dapat digunakan untuk melihat keindahan hutan mangrove dari ketinggian dan pondok ditengah hutan mangrove dan di pesisir pantai.

Akan tetapi, hutan mangrove di Dusun Magelo'o selama ini pengelolaannya belum maksimal, hal ini dilihat dari masih kurang adanya penyediaan fasilitas sarana dan prasaran penunjang di kawasan wisata. Ini dilihat dari beberapa fasilitas yang sudah rusak namun tidak ada perbaikan dan kurang adanya pengadaan fasilitas sarana dan prasaran dalam menunjang hutan mangrove untuk dijadikan kawasan ekowisata. Untuk itu, partisipasi masyarakat sangat diperlukan dalam pengelolaan kawasan hutan mangrove. Hal ini karena masyarakat merupakan 
pihak atau orang yang paling dekat dengan kawasan hutan mangrove dan yang paling bisa diharapkan dalam pengelolaan hutan mangrove.

Berdasarkan permasalahan diatas maka penelitian ini bertujuan untuk 1) mengetahui bentuk pengelolaan hutan mangrove, 2) mengetahui partisipasi masyarakat dalam pengelolaan hutan mangrove sebagai kawasan ekowisata dan 3) mengetahui faktor pendukung dan penghambat partisipasi masyarakat dalam pengelolaan hutan mangrove sebagai kawasan ekowisata.

\section{Metode Penelitian}

Penelitian ini menggunakan metode kualitatif dalam mengumpulkan dan menganalisis data. Pendekatan kualitatif adalah sebagai penelitian yang bermaksud untuk memahami fenomena tentang apa yang dialami oleh subjek penelitian misalnya, perilaku, persepsi, motivasi, dan tindakan. Penelitian ini merupakan jenis penelitian studi kasus. Dimana dalam penelitian ini peneliti ingin mengeksplorasi proses, aktivitas, dan peristiwa secara mendalam. Metode kualitatif dalam penelitian ini dapat digunakan untuk mengungkapkan fenomena yang berkaitan dengan partisipasi masyarakat dalam pengelolaan hutan mangrove sebagai kawasan ekowisata di Dusun Magelo'o Desa Reroroja Kecamatan Magepanda Kabupaten Sikka. Teknik pengumpulan data dalam penelitian ini dilakukan melalui 3 cara yaitu Observasi (pengamatan), wawancara (Interview) dan dokumentasi. Dimana pada penelitian ini terdapat 13 informan yang terdiri dari: 1 pengelola hutan mangrove, 9 masyarakat Dusun Magelo’o dan 3 dinas.

\section{Pengumpulan data}

Untuk memperoleh data-data yang diperlukan peneliti maka perlu dilakukan beberapa metode untuk pengumpulan data. Metode yang digunakan sebagai berikut:

Observasi

Peneliti melakukan observasi terhadap kawasan hutan mangrove yang tepatnya di Dusun Magelo'o Desa Reroroja Kecamatan Magepanda Kabupaten Sikka. Kegiatan observasi ini bertujuan untuk mengumpulkan data berupa bentuk pengelolaan hutan mangrove dan partisipasi serta aktivitas masyarakat dalam mengelola dan memanfaatkan kawasan hutan mangrove menjadi kawasan ekowisata.

Wawancara

Kegiatan wawancara dilakukan kepada pengelola kawasan hutan mangrove sebaagai informan kunci, 9 orang masyarakat di sekitar kawasan hutan mangrove, serta dinas-dinas terkait yang memiliki keterkaitan atau hubungan dengan kegiatan pengelolaan kawasan hutan mangrove ini.

Dokumentasi

Dalam penelitian ini dokumentasi diperoleh melalui dokemen arsip dari kantor desa berupa profil Desa Reroroja.

\section{Analisis data}

Analisis data yang digunakan dalam penelitian ini dengan menggunakan metode analisis data Miles dan Huberman. Miles dan Huberman (dalam Sugiyono 2017:137) mengemukakan bahwa aktivitas dalam analisis data, yaitu data collection, data reduction, data display, dan conclusion drawing/verification.

Data Collection (Pengumpulan Data)

Pengumpulan data dilakukan dengan observasi, wawancara dan dokumentasi. 


\section{Data Reduction (Reduksi Data)}

Reduksi data dilakukan dengan merangkum hasil pengumpulan data yang sudah dilakukan dengan pengkodean pada tiap- tiap fokus penelitian yang akan dibahas agar lebih mudah untuk mengelola data.

Data Display (Penyajian Data)

Penyajian data dilakukan dalam bentuk uraian singkat mengenai hasil dari reduksi data yang dilakukan untuk membahasi fokus penelitian yang diteliti.

Conclusion Drawing/Verification.

Verifikasi merupakan penarikan kesimpulan dari semua tahap analisis data.

\section{Hasil dan Pembahasan}

\section{Gambaran Umum Desa Reroroja}

Desa Reroroja merupakan salah satu Desa yang ada di Kecamatan Magepanda Kabupaten Sikka. Desa Reroroja memiliki batas wilayah di sebelah Utara berbatasan dengan Laut Flores, sebelah Selatan berbatasan dengan Desa Parabubu, sebelah Timur berbatasan dengan Desa Magepanda dan Desa Done, dan sebelah Barat berbatasan dengan Desa Tou Timur, kec. Kota Baru, kab Ende. Keadaan topografi sebagaian besar berbukit/ lereng/ curam diselingi dengan lembah dan dataran. Dengan luas wilayah Desa Reroroja yang seluas 41,974 $\mathrm{Km}^{2}$. Letak Desa Rerorja dapat dilihat pada gambar 3.1 berikut ini:

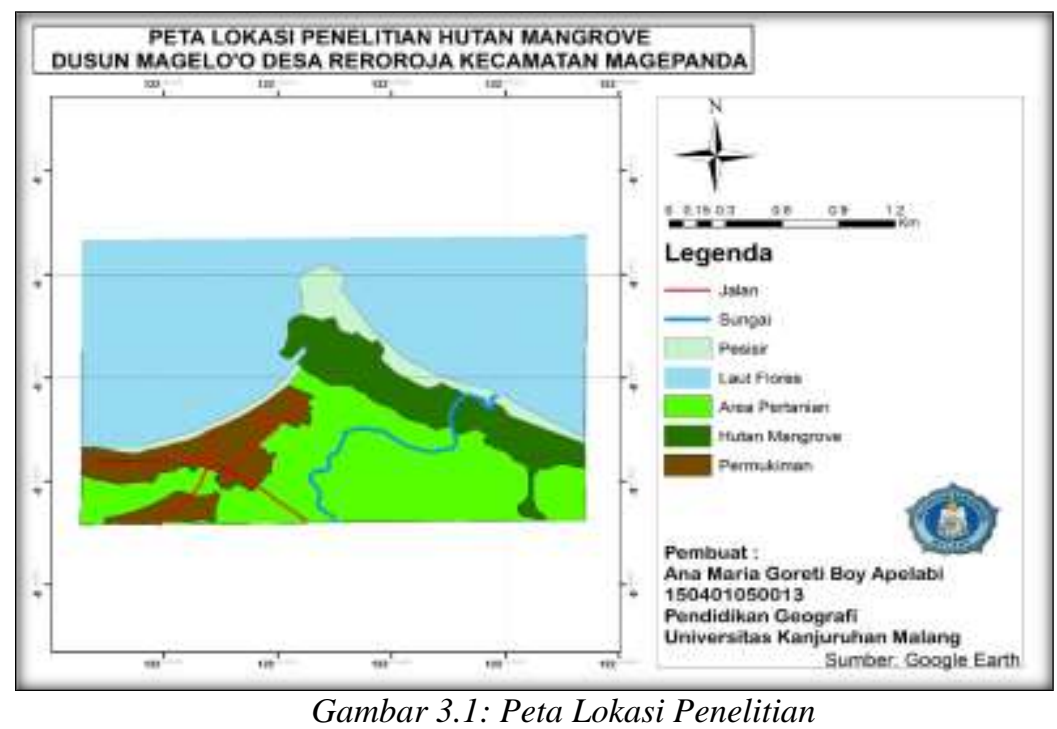

Jumlah penduduk Desa Reroroja sebesar 3.605 jiwa. Penduduk Desa Reroroja terdiri dari 1.763 jiwa laki-laki dan jumlah penduduk perempuan 1.842 jiwa. Jumlah kepala keluarga di Desa Reroroja terdiri dari 864 kepala keluarga (kk).

Pendidikan masyarakat di Desa Reroroja juga beragam. Pendidkan masyarakat di Desa Reroroja terdiri dari Jenjang Perguruan Tinggi 103 orang, SMU/ SMK 587 orang, SLTP/ sedejarat 803 orang, SD/ sederajat 1.845 orang, PAUD 267 orang.

Masyarakat di Desa Reroroja terdiri dari berbagai suku. Suku asli masyarakat di Desa Reroroja dalah suku Lio. Akan tetapi Desa Reroroja menjadi wilayah transmigran bagi para pendatang karena Desa Reroroja terletak di kawasan pesisir laut Flores. Suku yang datang dan menetap di Desa Reroroja adalah suku Bajo dan suku Buton. Masyarakat di Desa Reroroja banyak meganut agama Katolik dan Islam. Di Desa Reroroja terdapat 2 Gereja dan 1 Masjid. 
Masyarakat Desa Reroroja memiliki pekerjaan dalam bidang Pertanian, Perkebunan, Peternakan, Perikanan dan Kelautan. Rata-rata masyarakat yang bekerja sebagai petani dan peternak adalah masyarakat asli Desa Reroroja yaitu dari Suku Lio sedangkan yang bekerja sebagai nelayan adalah masyarakat pendatang yang berasal dari suku bajo/buton. Hal ini dikarenak masyarakat suku bajo/bugis yang menetap di kawasan pesisir Desa Reroroja sehingga mereka lebih memilih bekerja sebagai nelayan. Di Desa Reroroja juga terdapat unit usaha masyarakat yeng terdiri dari unit usaha mikro milik masyarakat. Unit usaha mikro di Desa Reroroja terdi dari 37 unit usaha seperti warung/kios-kios.

\title{
Bentuk Pengelolaan Hutan Mangrove di Dusun Magelo’o
}

\section{Konservasi}

Pengelolaan hutan mangrove di Dusun Magelo'o Desa Reroroja Kecamatan Magepanda dari awal hingga saat ini merupakan kawasan konservasi.

\begin{abstract}
"Bentuk pengelolaan hutan mangrove yang berada di Dusun Magelo'o Desa Reroroja Kecamatan magepanda ini pertama kali dikelola sebagai usaha Konservasi wilayah pesisir Jadi begini nona, awal mula saya menanam mangrove itu karena bencana yang terjadi tahun 1992 itu, saya waktu lari di bukit itu saya lihat kalau pesieis yang ada pohon-pohon itu aman sedangkan yang tidak ada pohon-pohon itu rusak habis semua. Jadi pas sudah mulai tenang di tahun 1993 saya ajak istri saya untuk tanam mangrove, waktu itu masyarakat yang lain itu tertawa dengan kami mereka bilang kalau usaha kami itu nanti sia-sia tapi kami tdak mau dengar kami terus tanam. Rusak kami perbaiki, mati kami tanam ulang begitu saja terus. Lama kelamaan masyarakat yang lain juga sudah mulai datang ikut tanam bibit, ikut tanam mangrove sampai sekarang ini. Jadi mangrove di sini sampai saat ini masih sebagai kawasa konservasi”. (Wawancara Babah Akong, 2019)

"Hutan mangrove ini pertama kali dijadikan sebagai tempat konservasi untuk menjaga kawasan pesisir dari abrasi, angin dan mengantisipasi dari bencana tsunami seperti yang pernah terjadi pada tahun 1992”. (Wawancara, Bapak Cornelis Dehotman, 2019) "Kawasan hutan mangrove ini pertama kali di kembangkan dengan tujuan konservasi dan perlindungan kawasan pesisir" (Wawancara, Bapak Eduardus Abdon, 2019)
\end{abstract}

Theodore Rosevelt dalam Mulyadi (2016) mengungkapkan bahwa konservasi juga dapat dipandang dari segi ekonomi dan ekologi dimana konservasi dari segi ekonomi berarti mencoba mengalokasikan sumberdaya alam untuk sekarang, sedangkan dari segi ekologi konservasi merupakan alokasi sumber daya alam untuk sekarang dan masa yang akan datang.

Kawasan konservasi hutan mangrove di Dusun Magelo'o Desa Reroroja juga memandang konservasi memberikan manfaat dalam segi ekonomi dan ekologi. Dilihat dari kegiatan yang dilakukan dalam memanfaatkan kawasan hutan mangrove dalam segi ekonomi seperti memanfaatkan hutan mangrove untuk sekarang dengan mengambil hewan laut yang hidup di ekosistem mangrove untuk di olah dan dikonsumsi oleh masyarakat dan segi ekologi yaitu melalui kegiatan pembibitan, penanaman, pemeliharaan dan pengawasan 
untuk mangrove yang rusak agar hutan mangrove terus diletarikan dan dapat terus memberikan manfaat bagi banyak orang.

Pembibitan

Kegiatan yang dilakukan oleh pengelola dan masyarakat dalam pengelolaan hutan mangrove sebagai wilayah konservasi dilakukan melalui pembibitan.

"Kami terus melakukakan pembibitan untuk keberlanjutan kawasan hutan mangrove disini serta penyediaan bibit sebagai kebutuhan untuk wilayah-wilayah yang membutuhkan bibit mangrove. Bibitbibit mangrove juga bisa menambah ekonomi masyarakat apabila ada yang mau membeli. Kami biasanya mendapat informasi dari dinas baik dari dinas lingkungan hidup maupun dari dinas kehutan apabila ada yang membutuhkan bibit mangrove dalam jumblah yang banyak". (Wawancara, Babah Akong, 2019)

"Membantu menanam bibit mangrove". (Wawancara, Ibu Eminoda Avrida, 2019)

"Kami sebagai fasilitator apabila ada yang membutuhkan bibit mangrove maka kami akan menghubungi pengelola dan mayarakat untuk membantu menyediakanya. Untuk itu kami mengajak masyarakat untuk terus melakukan pembibitan selain untuk kebutuhan penanaman di hutan mangrove Dusun magelo'o tapi masyarakat diajak untuk melakukan pembibitan yang dimana bibitbibit mangrove ini dapat dijadikan tambahan ekonomi bagi masyarakat”. (Wawancara, Bapak Yanto Dosi, 2019).

\section{Pemilihan Lokasi}

Kegiatan yang dilakukan dalam pengelolaan hutan mangrove sebagai kawasan konservasi di Dusun Magelo'o Desa Reroroja Kecamatan Magepanda adalah pemilihan lokasi. Pemilihan lokasi dilakukan sebelum melakukan penanaman.

"Kami melakukan pemilihan lokasi untuk dilakukan penanaman mangrove yang dilakukan bersama masyarakat. Jadi sebelum tanam kami perlu memilih lokasi mana saja yangg cocok dan perlu dilakukan penanaman supaya tidak salah”. (Wawancara, Babah Akong, 2019)

"Ikut dalam perencanaan, pemilihan lokasi". (Wawancara, Bapak Cornelis Dehotman, 2019).

\section{Penanaman}

Kegiatan selanjutnya yang dilakukan dalam pengelolaan hutan mangrove sebagai kawasan konservasi di Dusun Magelo’o Desa Reroroja Kecamatan Magepanda adalah penanaman.

"Kami melakukan penanaman, ini juga dilakukan bersama masyarakat, kadang ada pengunjung yang ikut dalam penanaman, 
dan juga pemerintah apabila ada kegiatan mereka juga ikut menanam". (Wawancara Babah Akong, 2019).

"Ikut dalam Penanaman Mangrove". (Wawancara, Bapak Yulius Demu, 2019).

"Upaya yang kami lakukan adalah terus mengadakan kegiatan penanaman di kawasan hutan mangrove dengan mengajak siswa dan masyarakat untuk terlibat dalam penanaman dengan tujuan mengajarkan semua pihak untuk peduli dengan menjaga dan melestarikan kawasan hutan mangrove”. (Wawancara Bapak Eduardus Abdon, 2019).

Pemeliharaan dan Pengawasan

Kegiatan yang juga dilakukan dalam pengelolaan hutan mangrove sebagai kawasan konservasi di Dusun Magelo’o Desa Reroroja Kecamatan magepanda adalah melalui kegitan pemeliharaan dan pengawasan.

"Masyarakat disini berpartisipasi dengan ikut terlibat dalam pengawasan dan juga pemeliharaan kawasan hutan mangrove". (Wawancara Babah Akong, 2019)

"Ikut pemeliharaan dan pengawasan kawasan hutan mangrove". (Wawancara Bapak Fransiskus Rego, 2019)

\section{Ekowisata}

Pengelolaan hutan mangrove di Dusun Magelo'o Desa Reroroja Kecamatan Magepanda tidak hanya sebagai kawasan konservasi tetepi sudah mulai dimanfaatkan sebagai kawasan ekowisata.

"Kawasan hutan mangrove mulai dikembangkan menjadi kawasan ekowisata sekitar tahun 2015. Pengunjung yang di kawasan hutan mangrove ini baik dari Kabupaten sikka, dari luar Kabupaten sikka bahkan para pengunjung asing. Upaya yang dilakukan untuk menjadikan hutan mangrove sebagai sebagai kawasan ekowisata yaitu dengan menyediakan sarana dan prasarana penunjang berupa jembatan bambu, pondok-pondok, kamar mandi/toilet, menara bambu, dan tempat sampah”. (Wawancara Babah Akong, 2019)

"Bentuk pengelolaan hutan mangrove ini berupa konservasi yang kemudian dimanfaatkan untuk wisata oleh masyarakat. Hutan mangrove mulai dijadikan tempat wisata pada tahun 2015". (Wawancara Ibu Eminoda Avrida, 2019)

"Saat ini sudah mulai dikembangkan menjadi ekowisata karena cukup banyak masyarakat yang senang melakukan wisata ke hutan mangrove. Upaya kami saat ini sudah bekerjasama dengan pemerintah pusat agar segera mendapat pendanaan agar perencanaan kami segera terlaksana. Rencana pengembanganya yaitu dengan penyediaan fasilitas pendukung berupa akses jalan, kamar mandi dan kamar bilas, pusat jajanan dan cindramata serta 
menambah promosi agar wisata mangrove ini menjadi lebih dikenal lagi”. (Wawancara Bapak Petrus Poling, 2019)

Ekowisata merupakan perjalanan wisata ke suatu lingkungan baik alam yang alami maupun buatan serta budaya yang ada yang bersifat informatif dan partisipatif yang bertujuan untuk menjamin kelestarian alam dan sosial-budaya (Subadra dalam Anthy,2013). Menurut Pratama (2017), Ekowisata merupakan paket perjalanan menikmati keindahan lingkungan tanpa merusak ekosistem yang ada. Ekowisata hutan mangrove di Dusun Magelo'o tetap menjaga keberlangsungan alam di dalamnya dimana pembangunan fasilitas penunjang wisata masih menggunakan bahan-bahan yang ramah seprti jembatan dari bambu, menara pandang bambu, dan pondok-pondok bambu. Selain keberlangsungan alam, ekowisata di hutan mangrove Dusun magelo'o juga memberikan manfaat ekonomi bagi pengelola dimana untuk masuk ke kawasan hutan mangrove pengunjung harus membayar Rp.5000 untuk pengunjung lokal dan Rp.10.000 untuk pengunjung asing.

Manfaat ekonomi lain bagi masyarakat sekitar dimana hewan-hewan yang ada di ekosistem mangrove seperti siput, kerang, kepiting dapat diolah dan dikonsumsi oleh masyarakat. Hutan mangrove di Dusun Magelo'o juga memberikan manfaat psikologi bagi masyarakat sekitar karena keberadaan hutan mangrove dapat memberikan jaminan keamanan bagi masyarakat sekitar dalam menjalanakan kehidupan mereka. Selain itu juga, hutan mangrove di Dusun Mangelo'o memberikan manfaat edukasi bagi masyarakat dan pengunjung dimana hutan mangrove di Dusun Magelo'o di jadikan tujuan wisata sambil belajar bagi sekolah-sekolah di Kabupaten Sikka, siswa- siswi ataupun pengunjung juga diajak untuk ikut dalam pembibitan dan penanaman mangrove baik yang dilakukan oleh sekolah-sekolah yang melakukan kunjungan maupun dari instansi atau dinas melalui program bersama sekolah-sekolah maupun masyarakat. Selain itu kawasan ekowisata mangrove juga dijadikan sebagai bahan belajar dan penelitian bagi mahasiswa yang ingin melakukan penelitian dikawasan hutan mangrove.

\section{Pendidikan}

Bentuk pengelolaan hutan mangrove di Dusun Magelo'o Desa Reroroja juga dimanfaatkan sebagai lokasi pendidikan.

"Kunjungan wisata yang dilakukan disini juga banyak dilakukan oleh sekolah-sekolah dengan melakukan kunjungan wisata dan adapula yang melakukan penanaman setiap kali melakukan kunjungan wisata". Banyak sekali manfaat yang diperoleh dari hutan mangrove ini selain sudah dijadikan tempat wisata dan memberi manfaat bagi pendidikan (edukasi). Pendidikan disini diberikan melalui kunjungan wisata sekolah-sekolah dan ikut dalam pembibitan maupun penanaman, selain itu manfaat pendidikan bagi mahasiswa yang ingin melakukan penelitian di hutan mangrove ini". (Wawancara Babah Akong, 2019).

"Pengunjung yang datang tidak hanya berwisata tapi ada pula dari sekolah-sekolah yang melakukan kunjungan belajar ke hutan mangrove dan ikut dalam penanaman mangrove dan banyak juga yang melakukan penelitian disini". (Wawancara Bapak Fransiskus Rego, 2019) 
"Kawasan hutan mangrove ini juga di jadikan sebagai tempat penelitian dan kunjungan dari sekolah-sekolah yang ada di Kabupaten Sikka”. (Wawancara Bapak Eduardus Abdon, 2019)

Kawasan hutan mangrove di Dusun Magelo’o di Desa Reroroja Kecamatan Magepanda Kabupaten Sikka selain dikelola sebagai kawasan konservasi dan ekowisata juga dikelola sebagai kawasan pendidikan (edukasi). Menurut Australian Departement of Tourism (dalam Linnas Khoirunnas, 2011) mendefinisikan ekowisata sebagai wisata berbasis pada alam dengan mengikutkan aspek pendidikan dan interpretasi terhadap lingkungan alami dan budaya masyarakat dengan pengelolaan kelestarian ekologis. Manfaat pendidikan (edukasi) bagi masyarakat dan pengunjung dimana hutan mangrove di Dusun Magelo'o di jadikan tujuan wisata sambil belajar bagi sekolah-sekolah di Kabupaten Sikka, siswa- siswi ataupun pengunjung juga diajak untuk ikut dalam pembibitan dan penanaman mangrove baik yang dilakukan oleh sekolah-sekolah yang melakukan kunjungan maupun dari instansi atau dinas melalui program bersama sekolah-sekolah maupun masyarakat. Selain itu kawasan ekowisata mangrove juga dijadikan sebagai bahan belajar dan penelitian bagi mahasiswa yang ingin melakukan penelitian dikawasan hutan mangrove.

\section{Partisipasi Masyarakat}

\section{Bentuk Partisipasi Masyarakat}

\section{Pikiran}

Masyarakat di Dusun Magelo'o Desa Rerroroja Kecamatan Magepanda ikut berpartisipasi dalam berbagai kegiatan dalam pengelolaan hutan mangrove di Dusun Magelo'o. Masyarakat memberikan partisipasi melalui kegiatan yang melibatkan pikiran mereka.

"Bentuk partisipasi yang diberikan masyarakat disini dengan ikut dalam perencanaan pengelolaan hutan mangrove dan pemilihan lokasi". (Wawancara Babah Akong, 2019)

"Ikut dalam perencanaan, pemilihan lokasi". (Wawancara Bapak Cornelis Dehotman, 2019)

\section{Tenaga}

Pengelolaan hutan mangrove sebagai kawasan ekowisata di Dusun Magelo'o Desa Reroroja melibatkan masyarakat dalam berbagai kegiatan. Bentuk partisipasi yang diberikan masyarakat tidak hanya berupa pikiran tetapi juga dalam bentuk tenaga.

"Partisipasi yang diberikan masyarakat juga diberikan melalui kegiatan seperti persiapan lahan, penyiapan bibit, penanaman, pengerjaan dalam menyedikan fasilitas penunjang ekowisata, pengawasan dan juga pemeliharaan kawasan hutan mangrove dan fasilitas ekowisata yang rusak dan memperbaikinya". (Wawancara Babah Akong, 2019).

"Partisipasi yang juga saya berikan berupa tenaga dengan membantu menanam bibit mangrove, pemeliharaan hutan mangrove dan fasilitas-fasilitas yang ada serta dengan menjaga 
hutan mangrove agar tidak dirusak". (Wawancara Ibu Yasinta Lawi, 2019)

Menurut Keith Davis dalam Erawati,dkk (2013) dikemukakan bahwa bentuk-bentuk dari partisipasi masyarakat adalah berupa: Pikiran, Tenaga, Pikiran dan Tenaga, Keahlian, Barang, Uang. Bentuk-bentuk partisipasi masyarakat yang diberikan masyarakat di Dusun Magelo'o Desa Reroroja Kecamatan Magepanda dalam pengelolaan hutan mangrove menjadi kawasan ekowisata berupa Pikiran dan Tenaga. Masyarakat memberikan pikiran dan tenaga dalam mengambil bagian dalam pengelolaan hutan mangrove. Pikiran masyarakat diberikan ketika mereka melakukan perencanaan bersama pengelola sebelum melaksanakan segala sesuatu yang berkaitan dengan pengelolaan hutan mangrove. Selain pikiran, masyarakat di Dusun Magelo'o Desa Reroroja juga berpartisipasi dengan memberikan tenaga mereka dalam berbagai kegiatan yang dilakasanakan dalam pengelolaan. Tenaga yang mereka berikan dapat berupa keterlibatan mereka dalam penyiapan lahan, pembibitan, penanaman, penyediaan fasilitas penunjang ekowisata serta pengawasan dan pemeliharaan kawasan hutan mangrove.

\section{Tahapan Partisipasi Masyarakat}

\section{Perencanaan}

Partisipasi masyarakat dalam pengelolaan hutan mangrove sebagai kawasan ekowisata memliki tahapannya. Tahapan yang pertama yang dilakukan masyarakat dalam partisipasi adalah perencanaan dalam berbagai kegiatan yang mereka laksanakan.

"Bentuk partisipasi yang diberikan masyarakat disini berupa ikut
dalam perencanaan pengelolaan hutan mangrove dan pemilihan
lokasi". (Wawancara, Babah Akong, 2019)
"Ikut dalam perencanaan pemilihan lokasi". (Wawancara Bapak
Cornelis Dehotman, 2019)

Menurut Siagian (dalam Novita, 2014) mengemukakan bahwa perencanaan (planing) merupakan keseluruhan proses pemikiran dan penentuan secara matang menyangkut hal-hal yang akan dikerjakan di masa datang dalam rangka mencapai tujuan yang telah ditentukan sebelumnya. Perencanaan yang dilakukan di kawasan hutan mangrove dimana pengelola bersama masyrakat melakukan perencanaan dengan berdiskusi dan bertukar pikiran melalui kegiatan pemilihan lokasi baik untuk penanaman maupun untuk fasilitas penunjang ekowisata dengan tujuan agar pengelolaan hutan mangrove sesuai dengan apa yang direncanakan.

\section{Pengorganisasian}

Dalam partisipasi masyarakat terdapat tahapan partisipasi yaitu pengorganisasian. Pengorganisasian disini adalah kerjasama antara pengelola, masyarakat dengan pihak-pihak lainnya.

"Instansi yang bekerjasama yaitu Dinas Kehutanan Kabupaten Sikka, Dinas Lingkungan Kabupaten Sikka dan Dinas Pariwisata. Pemerintah disini menjadi pengawas dan fasilitator dalam pengelolaan hutan mangrove. Pengawas disini dilakukan oleh dinas kehutanan yang menyediakan polisi hutan yang secara rutin melakukan pengawasan dikawasan hutan mangrove. Selain itu dinas kehutanan dan dinas lingkungan hidup berperan dalam 
perencanaan pengembangan dan penanaman kawasan hutan mangrove. Dinas Pariwisata berperan dalam perencanaan pengembangan ekowisata hutan mangrove saat ini". (Wawancara, Babah Akong, 2019)

"Pemerintah sering berkunjung dan membantu dalam penanaman, pengawasan dan juga dalam menjadikan tempat wisata”. ( Wawancara Bapak Cornelis Dehotman, 2019)

Menurut Stoner (dalam Novita, 2014) Pengorganisasian berarti mengkoordinasikan sumber daya manusia dan sumber daya bahan yang dimiliki organisasi. Dalam hal ini kemampuan manajer atau pimpinan untuk mengerahkan sumber daya yang ada dalam upaya mencapai tujuan sangat menentukan efektifitas organisasi tersebut. Seperti dalam partisipasi masyarakat di Dusun Magelo'o terdapat pihak pengelola yang berperan sebagai penggerak dalam partisipasi masyarakat, terdapat masyarakat yang berperan sebagai pelaksana dan pemerintah sebagai pengawas.

\section{Pelaksanaan}

Tahapan partisipasi masyarakat yang ketiga adalah pelaksanaan. Pada tahapan pelaksanaan ini masyarakat melaksanakan kegiatan yang telah direncanakan sebelumnya.

"Masyarakat ikut persiapan lahan, penyiapan bibit, penanaman, pengerjaan dalam menyedikan fasilitas penunjang ekowisata, pengawasan dan juga pemeliharaan kawasan hutan mangrove dan fasilitas ekowisata yang rusak dan memperbaikinya". (Wawancara Babah Akong, 2019)

"Ikut membantu dalam pembibitan, penanaman, pengecekan kalau ada mangrove yang rusak dan menyulam kembali, membatu dalam pemeliharaan mangrove dan fasilitas pendukungnya juga menjaga hutan mangrove”. (Wawancara Ibu Bertiana Nona, 2019)

Kartini Kartono (dalam Novita, 2014) mengatakan bahwa pelaksanaan adalah kegiatan penggerakan-pengendalian semua sumber dalam usaha pencapaian sasaran. Merupakan penyatuan semua usaha dan penciptaan kerja sama, sehingga tujuan dapat dicapai dengan lancar dan lebih efisien. Partisipasi masyarakat dalam pengelolaan hutan mangrove di Dusun Magelo'o juga menggerakan semua sumber yaitu sumber daya alam berupa ekosistem mangrove dan sumber daya manusia berupa masyarakat. Selain itu, partisipasi masyarakat dalam pelaksanaan di hutan mangrove Dusun magelo'o juga menciptakan kerjasama baik diantara masyarakat, pengelola dan juga pemerintah dengan tujuan agar pengelolaan hutan mangrove dapat berjalan dengan baik dan efisien.

\section{Monitoring dan Evaluasi}

Tahapan yang terakhir dalam partisipasi masyarakat adalah monitoring dan evaluasi. Masyarakat di Dusun Magelo'o Desa Reroroja juga berpartisipasi dalam tahapan monitoring dan evaluasi

"Masyarakat ikut dalam pengawasan dan juga pemeliharaan kawasan hutan mangrove". (Wawancara Babah Akong, 2019) 
"Ikut dalam pemeliharaan dan pengawasan kawasan hutan mangrove”. (Wawancara Bapak Yohanes Nuru, 2019)

Menurut Ibid (dalam Novita, 2014) Pengawasan adalah keseluruhan upaya pengamatan pelaksanaan kegiatan operasional guna menjamin bahwa kegiatan tersebut sesuai dengan rencana yang telah ditetapkan sebelumnya. Monitoring adalah alat untuk mengontrol. Dengan demikian controlling melakukan koreksi terhadap pelaksanaan dan untuk mengetahui apakah tujuan dapat tercapai. Teori ini sama dengan keadaan di lapangan yaitu di hutan mangrove Dusun Magelo'o dimana masyarakat juga berpartisipasi dalam kegiatan pengawasan dan perbaikan di kawasan hutan mangrove.

\section{Faktor Pendukung Partisipasi Masyarakat}

\section{Kesadaran}

Kesadaran merupakan salah satu faktor yang mendukung partisipasi masyarakat. Masyarakat sadar akan penting dan manfaat dari hutan mangrove yang selama ini sudah dirasakan sehigga masyarakat sadar untuk berpartisipasi dalam pengelolaan hutan mangrove.

"Faktor yang mendorong masyarakat disini berpartisipasi adalah kesadaran akan pentingnya serta manfaat yang diperoleh dari kawasan hutan mangrove ini". (Wawancara Babah Akong, 2019) "Sadar akan manfaat yang diperoleh dari adanya kawasan hutan mangrove”. (Wawancara Bapak Fransiskus Rego, 2019)

\section{Kemauan}

Faktor lain yang mendukung partisipasi masyarakat di Dusun Magelo’o Desa Reroroja Kecamatan Magepanda adalah kemauan. Kemauan menjadi faktor pendukung karena masyarakat sendiiri mau untuk berpartisipasi dalam pengelolaan hutan mangrove.

"Masyarakat disini juga senang apabila hutan mangrove dijadikan kawasan wisata karena dapat memperkenalkan Desa ke masyarakat luas sehingga mereka mau untuk berpartisipasi dalam pengelolaan hutan mangrove disini". (Wawancara Babah Akong, 2019)

"Mau agar hutan mangrove ini terus lestari dan berkembang sehingga manfaatnya dapat dirasakan banyak orang”. (Wawancara Bapak Yulius Demu, 2019)

Dorodjatun (dalam Deviyanti: 2013) dimana teori tersebut mengungkapakan faktor pendukung adalah munculnya suatu partisipasi yang merupakan suatu ekspresi perilaku manusia untuk melakukan suatu tindakan, dimana perwujudan dari perilaku tersebut didorong oleh adanya tiga faktor utama yang mendukung, yaitu (1) kemauan; (2) kemampuan; dan (3) kesempatan bagi masyarakat untuk berparisipasi. Faktor pendukung masyarakat di Dusun Magelo'o Desa Reroroja Kecamatan Magepanda untuk berpartisipasi karena kesadaran akan manfaat yang telah diperoleh sehingga masyarakat sadar akan lingkingan dan kemauan untuk melestarikan lingkungan sehingga masyarakat mau ikut berpartisipasi.

\section{Faktor Penghambat Partisipasi Masyarakat}




\title{
Waktu
}

Faktor yang menjadi penghambat dalam partisipasi masyarakat dalam pengelolaan mangrove sebagai kawasan ekowisata di Dusun Magelo'o Desa Reroroja Kecamatan magepanda adalah waktu.

\begin{abstract}
"Faktor yang menjadi penghambat partisipasi masyarakat disini adalah pekerjaan yang tidak bisa ditinggalkan untuk memenuhi kebutuhan sehari-hari. Masyarakat disini kebanyakan bertani dan nelayan apabila musim tanam dan panen tiba mereka kebanyakan ke kebun dan ladang untuk bekerja sehingga mereka sulit membagi waktu mereka. Mereka lebih mementingkan pekerjaan pokok mereka dibandingkan ikut dalam pengelolaan hutan mangrove. Masyarakat di sini juga kadang karena susah membagi waktu mereka jadi kerja setengah-setengah. Kadang mereka ikut dalam pembibitan kadan tidak.Ada yang hanya ikut tanam tapi tidak ikut pelihara apa bibit yang sudah mereka tanam".

"Saya kadang susah membagi waktu untuk bekerja dan membantu dalam pengelolaan hutan mangrove”. (Wawancara Ibu Eminoda Avrida, 2019)
\end{abstract}

\section{Ketergantungan}

Faktor yang juga menghambat partisipasi masyarakat dalam pengelolaan hutan mangrove sebagai kawasan ekowisata di Dusun Magelo'o Desa Reroroja adalah ketergantungan.

\footnotetext{
"Masyarakat disini juga masih kurang sadar karena mereka masih menganggap kalau hutan mangrove ini hanya menjadi tanggung jawab pengelola dan masyarakat sekitar saja sedangkan mereka merasa kurang peduli dan kurang bertanggung jawab terhadap hutan mangrove ini". (Wawancara Ibu Fransiska Xaveria Mite, 2019).
}

Menurut Watson (dalam Deviyanti: 2013) mengatakan bahwa ada beberapa kendala (hambatan) yang dapat menghalangi terjadinya suatu perubahan antara lain kendala yang berasal dari kepribadian individu salah satunya adalah ketergantungan. Faktor penghambat partisipasi masyarakat di Dusun Magelo'o dalam pengelolaan hutan mangrove adalah waktu. Waktu menjadi hambatan karena masyarakat harus bisa membagi waktu antara bekerja dan ikut berpartisipasi dalam pengelolaan hutan mangrove. Selain waktu, yang menjadi hambatan masyarakat dalam berpartisipasi alah ketergantungan. Ketergantungan menjadi faktor penghambat dalam partisipasi masyarakt karena masyarakat lebih bergantung terhadap pihakpihak tertentu yang masyarakat lebih memiliki tanggung jawab dalam pengelolaan hutan sehinggan masyarakat merasa bukan tanggung jawab mereka dalam pengelolaan hutan mangrove.

\section{Kesimpulan}


Bentuk pengelolaan yang ada di kawasan hutan mangrove di Dusun Magelo'o Desa Reroroja Kecamatan Magepanda Kabupaten Sikka adalah sebagai kawasan konservasi yang kemudian dimanfaatkan pula sebagai kawasan ekowisata dan pendidikan (edukasi). Partisipasi yang diberikan masyarakat dalam pengelolaan hutan mangrove berupa pikiran dan tenaga. Pikiran diberikan pada saat melakukan perencanaan bersama pengelola dan pemerintah. Tenaga yang mereka berikan dapat berupa keterlibatan mereka dalam penyiapan lahan, pembibitan, penanaman, penyediaan fasilitas penunjang ekowisata serta pengawasan dan pemeliharaan kawasa hutan mangrove. Partispasi masyarakat dalam pengelolaan hutan mangrove sebagai kawasan ekowisata di Dusun Magelo'o Desa Reroroja Kecamatan Magepanda dilakukan oleh pengelola dan masyarakat dalam setiap tahapannya yang bekerjasama dengan pemerintah. Tahapan partisipasi yang terdiri dari perencanaan (planing), pengorganisasian (organizing), pelaksanaan (actuating) sampai pada monitoring dan evaluasi (controling). Faktor pendukung dalam partisipasi masyarakat di Dusun Magelo'o Desa Reroroja Kecamatan Magepanda berupa kesadaran dan kemauan untuk berpartisipasi. Sedangkan faktor penghambat pastisipasi masyarakat di Dusun Magelo'o Desa Reroroja Kecamatan Magepanda adalah waktu bekerja dan ketergantungan kepada pihak-pihak lain yang dirasa lebih bertanggung jawab dalam pengelolaan kawasan hutan mangrove. Saran agar penelitian ini dapat dijadikan acuan bagi peneliti lain untuk mengambil judul tentang partisipasi masyarakat dalam pengelolaan hutan mangrove sebagai kawasan ekowisata.

\section{Ucapan Terimakasih}

Peneliti menyampaikan ucapan terimakasih kepada Universitas Kanjuruhan Malang, Hutan Mangrove Dusun Magelo'o sebagai lokasi penelitian, Pengelola hutan mangrove, Masyarakat Dusun Magelo'o, Dinas-dinas terkait seperti Dinas Kehutanan, Dinas Lingkungan Hidup dan Dinas Pariwisata yang telah membantu selama proses pengumpulan data.

\section{Daftar Rujukan}

Anthy, Hardianty. 2013. Pengelolaan Ekosistem Mangrove untuk pengembangan kawasan ekowisata di Pantai Boe Kecamatan Galesong Takalar., (Online), (http//repository.unhas.ac.id), diakses pada 18 November 2018

Deviyanti, Dea. 2013. Studi Tentang Partisipasi Masyarakat Dalam Pembangunan Di Kelurahan Karang Jati Kecamatan Balikpapan Tengah. e-Journal Administrasi Negara, (Online), (http://ejournal.an.fisip-unmul.org), diakses pada 02 Desember 2018.

Erawati, Intan, dkk. 2013. Partisipasi Masyarakat Dalam Pengelolaan Sumber Daya Lingkungan Mangrove Di Desa Bedono Kecamatan Sayung. Jurnal Ruang ,(Online), (https://ejournal3.undip.ac.id/index.php/ruang/article/view/2821), diakses pada 4 juli 2018.

Linnas, Khoirunnas. 2011. Ekowisata dan Pendidikan. Geografi Lingkungan, (Online), (http://geoenviron.blogspot.com/2011/1), diakses pada 5 juli 2019

Mulyadi, Edi,dkk. 2016. Konservasi Mangrove Sebagai Kawasan Ekowisata. Jurnal Ilmiah Teknik Lingkugan, (Online), (http://eprints.upnjatim.ac.id/1265), diakses pada 26 September 2018. 
Novita, Reni. 2014. Manajemen Kegiatan Ekstrakurikuler di Madrasah Tsanawiyah Negeri Lipatkain Kampar, (Online), (http://repository.uin.suska.ac.id), diakses pada 14 April 2019

Pratama, Firman W. 2017. Identifikasi Potensi dan Strategi Pengembangan Ekowisata Mangrove Pada Kawasan Wisata Tanarajae Kecamatan Lebbakkang Kabupaten Pangkep. Skripsi tidak diterbitkan. Makasar: UNHAS.

Rangkuti, Ahmad, dkk. 2017. Ekosistem Pesisir dan Laut Indonesia. Jakarta: Bumi Aksara. Sugiyono. 2017. Metode Penelitian Kualitatif. Bandung: Alfabeta. 